length polymorphism ( $L L$ ). The two remaining pedigrees studied had diabetic members doubly heterozygous for fragment length polymorphisms, and our results showed no linkage between maturity onset diabetes of the young and the variable region polymorphism. In family 1 the diabetic patients did not share any of the three different short polymorphisms foundthat is, $\mathrm{L}^{\mathrm{a}}, \mathrm{L}^{\mathrm{b}}$, or $\mathrm{L}^{\mathrm{c}}$. In family 2 all three diabetic members shared a short polymorphism (L). The propositus (subject IV 2), however, had clearly inherited his diabetes and the long polymorphism (U) from his mother and the short polymorphism (L) from his non-diabetic father (fig 3). Thus the diabetes was evidently not linked to the short polymorphism (L).

These pedigrees show the usefulness of the insulin fragment length polymorphism as a genetic marker. In the two families studied maturity onset diabetes of the young was clearly not linked to a defect in or around the insulin gene. The discovery of the chromosomal location of the presumed abnormal gene present in this type of diabetes must await the application of new genetic markers.

We thank G Bell for the gift of the insulin probe pH Ins 214 . Correspondence to JSW.

\section{References}

1 Pyke DA. Diabetes: the genetic connections. Diabetologia 1979;17:333-43.

2 Rotter JI, Rimoin DL. The genetics of the glucose intolerance disorders. Am $\mathcal{F}$ Med $1981 ; 70: 116-26$

${ }^{3}$ Tattersall RB. Mild familial diabetes with dominant inheritance. $Q \mathcal{F}$ Med $1974 ; 43: 339-57$.

4 Tattersall RB, Fajans SS. A difference between the inheritance of classical juvenile-onset and maturity-onset type diabetes in young people. Diabetes $1975 ; 24: 44-53$.

${ }^{5}$ Platz P, Jakobsen BK, Suejgaard A, et al. No evidence for linkage between $\stackrel{\mathbb{Q}}{\Omega}$ HLA and maturity onset type of diabetes in young people. Diabetologia $C$ $1982 ; 23: 16-8$

${ }^{6}$ Bell GI, Karam JH, Rutter WJ. Polymorphic DNA region adjacent to the $5^{\prime}$ end of the human insulin gene. Proc Natl Acad Sci USA $1981 ; 78$ : 5759-63.

Barbosa J, Ramsay R, Goetz FC. Plasma glucose, insulin, glucagon and $\mathbb{D}$ growth hormone in kindreds with maturity-onset type of hyperglycemia $\mathrm{T}$ in young people. Am $\mathcal{F}$ Med 1978;88:595-601.

${ }^{8}$ Fajans SS, Floyd J, Tattersall R, Williamson J, Pek S, Taylor C. The various faces of diabetes in the young. Arch Intern Med 1976;136: 114-202.

9 Old JM, Higgs DR. Gene analysis. In: The thalassaemias: methods in haematology. Edinburgh: Churchill Livingstone, 1982:74-102.

10 Southern EM. Detection of specific sequences among DNA fragments $\overline{\bar{\sigma}}$ separated by gel electrophoresis. F Mol Biol 1975;98:503-17.

1 Ullrich A, Dull TJ, Gray A, Phillips JA III, Peter S. Variation in the sequence and modification state of the human insulin gene flanking regions. Nucleic Acids Res 1982;10:2225-40.

12 Bell GD, Pictet RL, Rutter WJ, Cordell B, Tischer E, Goodman HM. Sequence of the human insulin gene. Nature 1980;284:26-32.

${ }^{13}$ Bell GI, Selby MT, Rutter WJ. The highly polymorphic region near the $\vec{\omega}$ human insulin gene is composed of simple tandemly repeating sequences. Nature $1982 ; \mathbf{2 9 5}: 31-5$.

i Rotwein P, Chyn R, Chirgwin J, Cordell B, Goodman HM, Permutt M. Polymorphism in the 5 ' flanking region of the human insulin gene and its possible relation to type 2 diabetes. Science $1981 ; 213: 1117-20$.

15 Owerbach D, Nerup J. Restriction fragment length polymorphism of the insulin gene in diabetes mellitus. Diabetes $1982 ; 31: 275-7$.

16 Bell GI, Horita S, Karam JH. A polymorphic locus adjacent to the human of insulin gene and diabetes mellitus. Diabetes 1982;31,suppl 2:65A. 응
(Abstract.)

17 Owerbach D, Poulsen S, Billesbolle P, Nerup J. DNA insertion sequences $O$ near the insulin gene affect glucose regulation. Lancet $1982 ; \mathrm{i}: 880-3$.

(Accepted 11 fanuary 1983)

\title{
Transient neonatal hyperthyrotrophinaemia: a serum abnormality due to transplacentally acquired antibody to thyroid stimulating hormone
}

\author{
JOHN H LAZARUS, RHYS JOHN, JODY GINSBERG, IEUAN A HUGHES, GERALD SHEWRING, \\ BERNARD REES SMITH, J STUART WOODHEAD, REGINALD HALL
}

\begin{abstract}
In a screening programme for neonatal hypothyroidism an otherwise healthy female infant was found to have a high concentration of thyroid stimulating hormone in a filter paper blood spot and in serum. A high concentration was also found in the maternal serum. Mother and baby
\end{abstract}

\footnotetext{
Department of Medicine, Welsh National School of Medicine, University Hospital of Wales, Heath Park, Cardiff CF4 4XN JOHN H LAZARUS, MD, FRCPGLAS, senior lecturer

JODY GINSBERG, MD, research fellow (present appointment: senior resident, University of Alberta, Canada) GERALD SHEWRING, BSC, biochemist

BERNARD REES SMITH, PHD, reader

REGINALD HALL, MD, FRCP, professor

Department of Medical Biochemistry, Welsh National School of Medicine

RHYS JOHN, PHD, MRCPATH, principal biochemist

J STUART WOODHEAD, PHD, senior lecturer

Department of Child Health, Welsh National School of Medicine IEUAN A HUGHES, MD, MRCP, senior lecturer
}

were both biochemically euthyroid with normal serum thyroxine concentrations. The apparently high concen- $\mathcal{O}$ tration of thyroid stimulating hormone in the mother was due to the presence of an IgG antibody that bound ? to human but not bovine thyroid stimulating hormone. N Maternal serum inhibited the action of human thyroid stimulating hormone in an in vitro bioassay for the hormone.

It is suggested that the baby acquired the antibody transplacentally, especially as the concentration of $\mathrm{w}$ thyroid stimulating hormone subsequently fell. It is? concluded that maternal serum should be assayed foro thyroid stimulating hormone when a neonate is found $\Phi$ to have a high concentration of the hormone and $a^{+}$ normal concentration of thyroxine to establish the $\frac{T}{T}$ incidence of this finding and to avoid inappropriate $\frac{\vec{\Phi}}{\mathbb{D}}$ replacement treatment.

\section{Introduction}

Neonatal hypothyroidism may now be detected by screening thyroid hormone concentrations in blood obtained by heel 
prick stab at around five to seven days after birth, ${ }^{1}$ but many centres in Europe ${ }^{2}$ and some in North America $^{3}$ measure the concentration of thyroid stimulating hormone on a filter paper blood spot at the initial screen. The incidence of results incorrectly indicating raised concentrations is low, but transient neonatal hyperthyrotrophinaemia of unknown cause has occurred. ${ }^{4}$ We report a case of neonatal hyperthyrotrophinaemia due to transplacental passage of a maternal antibody to human thyroid stimulating hormone that led to high results in a radioimmunoassay for the hormone.

\section{Patient and methods}

A full term female infant weighing $3200 \mathrm{~g}$ was reviewed because a raised concentration of thyroid stimulating hormone was found on a filter paper whole blood spot taken seven days after birth. The infant had been delivered normally, and there was no history of drug ingestion during pregnancy or of maternal illness. Clinical examination of the child was normal; in particular there was no goitre or features of hypothyroidism. She was being breast fed. The mother, aged 35, was clinically euthyroid with no goitre. There was no history of illness or recent immunisation and no family history of thyroid disease or parental consanguinity.

Concentrations of thyroxine, ${ }^{5}$ triiodothyronine, free thyroxine, ${ }^{6}$ thyroxine binding globulin, prolactin, luteinising hormone, follicle stimulating hormone, and $\beta$-human chorionic gonadotrophin were measured by radioimmunoassay. Concentration of thyroid stimulating hormone was measured by an immunoradiometric assay. ${ }^{7}$ Fujizoki and Burroughs Wellcome kits were used to measure antimicrosomal and antithyroglobulin antibodies respectively. For subsequent experiments bovine ${ }^{8}$ human, ${ }^{9}$ and iodine-125 $\left({ }^{125} \mathrm{I}\right)$ labelled human (Nuclear Medical Laboratories) thyroid stimulating hormone were used.

A crude immunoglobulin fraction was obtained by polyethylene glycol precipitation and used at a concentration of $10 \mathrm{~g} / \mathrm{l}$. Pure maternal IgG was prepared from the precipitate by diethylaminoethanol chromatography. ${ }^{10}$ To investigate the binding properties of the maternal immunoglobulin $100 \mu$ l polyethylene glycol precipitate $(10 \mathrm{~g} / \mathrm{l})$ from maternal or normal serum was added to $100 \mu 1 \%$ Lubrol. This mixture was then incubated for one hour at $37^{\circ} \mathrm{C}$ with ${ }^{125}$ I human or bovine $(5000 \mathrm{cpm})$ thyroid stimulating hormone. The effect on binding of adding high concentrations $(1000 \mu \mathrm{U})$ of unlabelled human or bovine thyroid stimulating hormone was measured. Free and buund hormone were separated by centrifugation after addition of $200 \mu \mathrm{l}$ TRIS sodium chloride buffer containing bovine serum albumin $1 \mathrm{~g} / \mathrm{l}$ and $500 \mu \mathrm{l} 30 \%$ polyethylene glycol in $1 \mathrm{~mol}$ sodium chloride. Similar binding studies were performed with purified maternal and normal IgG $(5 \mathrm{~g} / \mathrm{l})$.

To determine whether the binding of human thyroid stimulating hormone by maternal IgG might interfere with the biological activity of the hormone the effect of the maternal polyethylene glycol precipitate was studied in a bioassay system for human thyroid stimulating hormone. ${ }^{11}$ This assay measures the ability of thyroid stimulating hormone to stimulate iodine organification by cultured porcine thyroid follicular cells. At the end of the incubation the cells were dissolved in $1 \mathrm{~mol}$ sodium hydroxide and ${ }^{125} \mathrm{I}$ organification was assessed by counting the pellets obtained by trichloracetic acid precipitation.

\section{Results}

The concentration of thyroid stimulating hormone on the filter paper blood sample obtained from the baby seven days after birth was $104 \mathrm{mU} / 1$. Repeat testing on the same filter paper spot and on a fresh filter paper spot gave similar results. Serum concentrations were: thyroxine $180 \mathrm{nmol} / 1(14.0 \mu \mathrm{g} / 100 \mathrm{ml})$, free thyroxine $22 \mathrm{pmol} / 1$ $(1 \cdot 7 \mathrm{ng} / 100 \mathrm{ml})$, triiodothyronine $3.1 \mathrm{nmol} / 1(202 \mathrm{ng} / 100 \mathrm{ml})$, and thyroxine binding globulin $25.5 \mathrm{mg} / \mathrm{l}$. These results were all normal. Serum bilirubin concentration was normal. Other serum hormone concentrations were prolactin $1520 \mathrm{mU} / 1$, luteinising hormone $2.8 \mathrm{U} / \mathrm{l}$, follicle stimulating hormone $4.7 \mathrm{U} / 1$, and $\beta$-human chorionic gonadotrophin $<2.5 \mathrm{IU} / 1$ (normal less than $5 \mathrm{IU} / 1$ ). No thyroid antibodies were detected in the baby's serum. A thyroid scan using ${ }^{123}$ I confirmed the presence of a functioning gland in the normal position.
Maternal thyroid function tests 10 days post partum showed the following concentrations: serum thyroxine $80 \mathrm{nmol} / \mathrm{l}(6 \cdot 2 \mu \mathrm{g} / 100 \mathrm{ml})$ (normal ranges $55-150 \mathrm{nmol} / 1(4 \cdot 3-11.7 \mu \mathrm{g} / 100 \mathrm{ml})$ ), free thyroxine $14 \mathrm{pmol} / \mathrm{l}(1 \cdot 1 \mathrm{ng} / 100 \mathrm{ml}$ ) (normal range $9-22 \mathrm{pmol} / 1$ (0.7-1.7 ng/100 $\mathrm{ml}$ )), triiodothyronine $1.6 \mathrm{nmol} / \mathrm{l}(104 \mathrm{ng} / 100 \mathrm{ml}$ ) (normal range $1.5-3.5 \mathrm{nmol} / 1(98-228 \mathrm{ng} / 100 \mathrm{ml})$ ), and thyroxine binding globulin $28.5 \mathrm{mg} / 1$ (normal range $12-31 \mathrm{mg} / \mathrm{l}$ ). No circulating thyroid antibodies were found. The raised concentration of thyroid stimulating hormone rose by $25 \% 20$ minutes after thyrotrophin releasing hormone (200 $\mu \mathrm{g}$ ) was given intravenously, from 33.1 to $41.1 \mathrm{mU} / 1$ (immunoradiometric assay). Serum triiodothyronine concentration rose from 1.6 $\mathrm{nmol} / 1(104 \mathrm{ng} / 100 \mathrm{ml})$ to $1.8 \mathrm{nmol} / 1(117 \mathrm{ng} / 100 \mathrm{ml})$ two hours after thyrotrophin releasing hormone was given, indicating release of biologically active thyroid stimulating hormone. Serum prolactin concentration was $3649 \mathrm{mU} / 1$ (while breast feeding; normal $<420$ $\mathrm{mU} / \mathrm{l}$ ), luteinising hormone $3.9 \mathrm{U} / \mathrm{l}$, follicle stimulating hormone $4.4 \mathrm{U} / 1$, and $\beta$-human chorionic gonadotrophin $1 \mathrm{IU} / 1$ (normal $<5$ IU/1). Urea and electrolyte concentrations, results of routine liver function tests, and serum IgG, IgA, and $\operatorname{IgM}$ concentrations were all normal. Results of a screening test for rheumatoid arthritis were negative.

A venous blood sample taken 13 days post partum showed a concentration of thyroid stimulating hormone in undiluted baby serum to be $48 \mathrm{mU} / 1$ and in serum diluted one in four $123 \mathrm{mU} / 1$. Dilutions of maternal and baby sera in serum that was free of thyroid stimulating hormone produced curves in both assays that were not parallel to the MRC 68/38 thyroid stimulating hormone standard (figure). Addition of sheep and rabbit IgG to the two-site immunoradiometric assay of thyroid stimulating hormone in amounts up to $5 \mathrm{mg}$ per assay tube failed to produce normal concentrations of thyroid stimulating hormone in the mother's serum. Addition of normal rabbit or sheep serum also failed to produce normal maternal concentrations. Addition of purified maternal IgG $(2.5 \mathrm{~g} / \mathrm{l})$ to the assay without serum gave a concentration of $26 \mathrm{mU}$ of the hormone/ 1 compared with a zero concentration when normal IgG was used in a separate assay.

There was appreciable binding of the maternal IgG precipitate and purified IgG to human thyroid stimulating hormone but not bovine thyroid stimulating hormone. This binding could be inhibited by
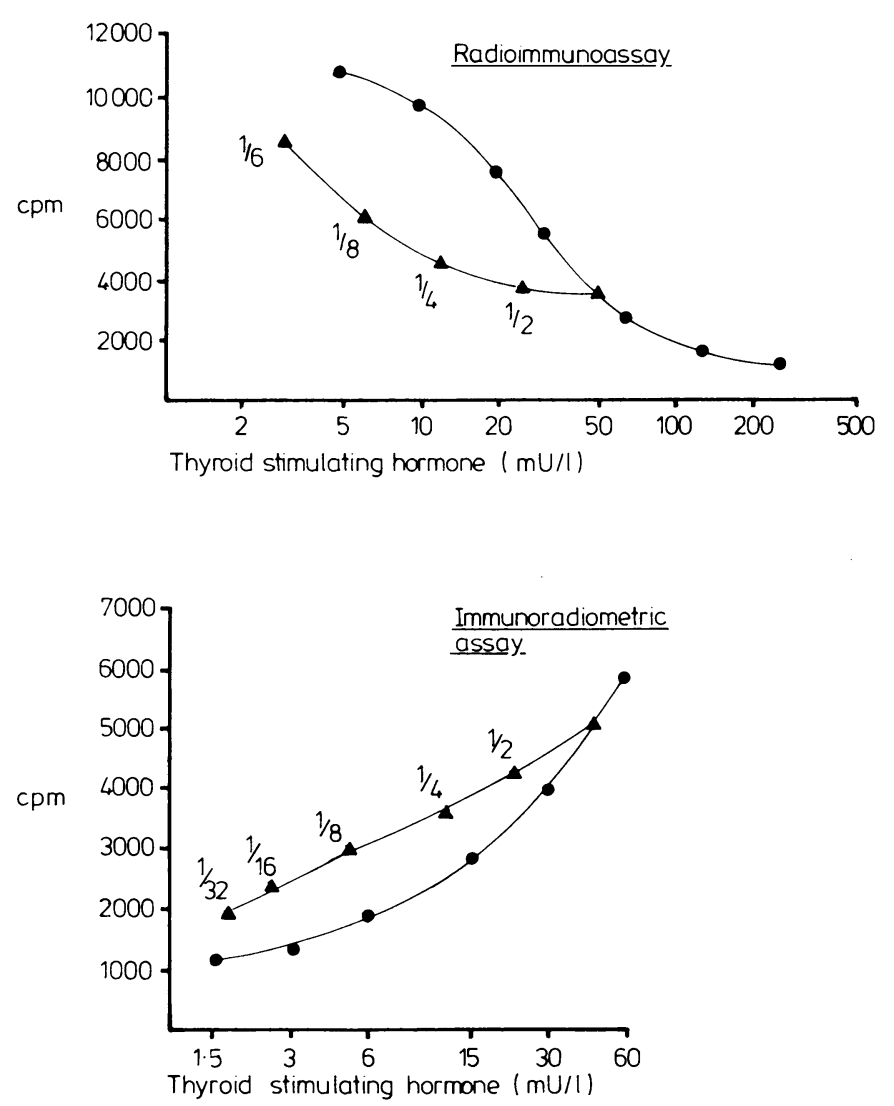

Dilutions of maternal serum assayed for thyroid stimulating hormone by radioimmunoassay and immunoradiometric assay. - $=$ Standard curve. $\nabla-\nabla=$ Dilutions of maternal serum in triiodothyronine suppressed serum. 
adding large amounts of "cold" thyroid stimulating hormone (table). The maternal IgG precipitate also inhibited the action of human thyroid stimulating hormone in the bioassay system. The maternal concentration of thyroid stimulating hormone measured seven months post partum was $28 \mathrm{mU} / \mathrm{l}$, while the concentration in the baby at that time had fallen to within the normal range $(<5 \mathrm{mU} / \mathrm{l})$.

Thyroid stimulating hormone (TSH) binding and bioassay activity of IgG precipitate from normal serum and maternal serum, and binding of purified IgG to human TSH (values are means of triplicates)

\begin{tabular}{|c|c|c|c|c|}
\hline Experiment & $\begin{array}{l}\text { Sample } \\
\text { added }\end{array}$ & $\begin{array}{l}\text { Human } \\
\text { TSH } \\
\text { added } \\
(\mathrm{mU} / \mathrm{l})\end{array}$ & $\begin{array}{c}\text { Control } \\
\text { sample } \\
\left(\begin{array}{c}0 \\
0\end{array} \text { binding }\right)\end{array}$ & $\begin{array}{l}\text { Maternal } \\
\text { sample } \\
(0, \text { binding })\end{array}$ \\
\hline TSH binding & $\begin{array}{l}\text { IgG precipitate* } \\
\text { IgG } \dagger\end{array}$ & $\left\{\begin{array}{c}0 \\
10^{4} \\
0 \\
10^{4}\end{array}\right.$ & $\begin{array}{l}4 \\
5 \cdot 3 \\
2 \\
2 \cdot 5\end{array}$ & $\begin{array}{r}22 \cdot 1 \\
6 \cdot 6 \\
10 \cdot 4 \\
2 \cdot 9\end{array}$ \\
\hline TSH bioassay & IgG precipitate & $\left\{\begin{array}{l}1 \\
10\end{array}\right.$ & $\begin{array}{l}100_{+}^{+} \\
100_{+}^{+}\end{array}$ & $\begin{array}{l}60 \\
60\end{array}$ \\
\hline
\end{tabular}

No significant binding of maternal IgG precipitate or purified maternal IgG to bovine thyroid stimulating hormone was observed. In the bioassay there was no significant difference in organification between control and maternal samples when no thyroid stimulating hormone was added.

* $10 \mathrm{~g} / 1$

†Organification control expressed as $100^{\prime \prime} \ldots$.

\section{Discussion}

This baby had a high concentration of thyroid stimulating hormone as measured by the conventional assay used in screening for neonatal hypothyroidism and confirmed on examination of the serum with two independent radioimmunoassays. The high concentration of the hormone in the maternal serum and the subsequent biochemical investigations on both sera suggested that the concentrations in the baby and mother were falsely raised. In addition the baby had normal serum concentrations of thyroid hormones and the gland was in the normal position on scanning.

Thyroid function was normal in the mother, who appeared to have a normal response of thyroid stimulating hormone to thyroid releasing hormone, though this test is difficult to evaluate because of the high background value.

Falsely raised serum concentrations of thyroid stimulating hormone have been described in adults, and Hendenborg et al ${ }^{12}$ found that in $5 \%$ of all sera with high concentrations these were due to the presence of heterophilic antibodies against rabbit IgG. The high concentrations were abolished if small amounts of rabbit IgG were added to the serum before assay. There are reports of false hyperthyrotrophinaemia due to the presence of heterophilic antibodies to thyroid stimulating hormone in paired maternal and neonatal sera obtained in screening programmes..$^{13-15}$ Some of these antibodies bind to the hormone in addition to acting as heterophilic antibodies. ${ }^{15}$ In one study all mothers had received injections of a microbial vaccine containing rabbit serum, and possibly the antibodies were transferred to the fetus during pregnancy.

We believe that the material from the mother had no heterophilic antibody activity as the thyroid stimulating hormone concentration in the assay could not be normalised despite the addition of large quantities of IgG from sheep and rabbit. Moreover, non-parallelism with the standard curve for the hormone was observed on serial dilution, and there was no history of recent immunisation or injection of foreign protein in the mother. We established that the interfering substance in the maternal serum was contained in the $\mathrm{IgG}$ fraction and was indeed an IgG. We have no information on the binding characteristics of the IgG. The thyroid stimulating hormone binding globulins described by Biró ${ }^{16}$ bound to bovine hormone, whereas ours showed binding to only the human hormone. The relation, if any, between the two types of antibodies is not clear. The pronounced binding of this IgG to human but not bovine thyroid stimulating hormone strongly suggests that the mother had an antibody to the human hormone that was? transferred to the baby. Antibodies to human thyroid stimulatinge hormone have been shown in the serum of some dwarfs with hypopituitarism, ${ }^{17}$ but this is a rare phenomenon and does not $\widetilde{\Omega}$ seem to be present in the sera of patients with pituitary tumours. We have no indication of why this maternal antibody appeared in the circulation, especially as the mother was entirely well and had no history of immune disorder.

The incidence of transient hyperthyrotrophinaemia is nor known, but two studies have shown incidences of between roughly one in 1000 and one in 10000 live births. One case waso described in which the maternal concentration of thyroid stimulating hormone was normal, ${ }^{18}$ but in others ${ }^{4}$ maternal sera⿳亠口冋. were not examined.

This case has important implications for neonatal hypothyroid screening programmes that use measurement of concentrations $s^{\mathrm{S}}$ of thyroid stimulating hormone as the initial test. The incidencee of this condition is not known, and it is important to avoid inappropriate replacement treatment. Clearly, any infant found to have a high concentration of thyroid stimulating hormoneo but in whom the serum thyroxine concentration is within norma? limits and who has a demonstrable thyroid gland in the normain position must be evaluated for a false positive result. Maternal concentrations of thyroid stimulating hormone and thyroide్ function should be checked and, if laboratory facilities permit, $\mathrm{N}$ appropriate tests done to determine the cause of the raisedir hormone concentration.

\section{References}

1 Anonymous. Screening for congenital hypothyroidism. (Editorial.) Bre Med f $1980 ; 281: 1-2$.

${ }^{2}$ Newborn Committee of the European Thyroid Association. Neonatal screening for congenital hypothyroidism in Europe. Acta Endocrinok 1979;90,suppl 223:5-29.

${ }^{3}$ Fisher DA, Dussault JH, Foley TP, et al. Screening for congenital hypothyroidism: results of screening one million North American infants. $\mathcal{F}$ Pediatr 1979;94:700-5.

- Miyai K, Harada T, Nose O, et al. Transient infantile hyperthyrotropin emia. In: Stockigt JR, Nagataki S, eds. Thyroid research VIII. Canberra Australian Academy of Science, 1980:33-6.

5 Challand CS, Ratcliffe WA, Ratcliffe JG. Semi automated radioimmuno $\frac{\mathbb{D}}{\square}$ assay for total serum thyroxine and triiodothyronine. Clin Chim Acta $1975 ; 60: 25-32$.

${ }^{6}$ Kadury S, John R, Woodhead JS, Kurtz AB. Automated radioimmuno assay of total and free thyroxine in human serum. Ann Clin Biochem? 1981;18:97-101.

${ }^{7}$ John R, Woodhead JS. An automated immunoradiometric assay of thyrotrophin (TSH) in dried blood filter paper spots. Clin Chim Actos $1982 ; 125: 329-40$.

${ }^{8}$ Smith BR, Hall R. Measurement of thyrotropin receptor antibodies Methods Enzymol $1981 ; 74: 405-20$.

${ }^{9}$ Stockell-Hartree A. Separation and partial purification of the proteit hormones from human pituitary glands. Biochem 7 1966;101:754-61. 응

10 Levy HB, Sober HA. A simple chromatographic method for preparation of gamma globulin. Proc Soc Exp Biol Med 1960;103:250-2.

11 Plannells R, Fayet G, Lissitzky S, Hennen D, Closset J. Bioassay of thyrotropin using isolated thyroid cells. FEBS Lett 1975;53:87-91. N

12. Hendenborg G, Pettersson T, Caristroom A. Heterophilic antibodies causing falsely raised thyroid-stimulating hormone results. Lance $1979 ;$ ii : 755 .

${ }^{13}$ Gendrel D, Feinstein MC, Grenier MR, et al. Falsely elevated serum thyrotropin (TSH) in newborn infants: transfer from mothers to infant of a factor interfering in the TSH radioimmunoassay. $\mathcal{F}$ Clin Endocrinod Metab $1981 ; 52: 62-5$.

1 Schaison G, Thomopoulos P, Moulias R, Feinstein MC. False hyperthyrotropinemia induced by heterophilic antibodies against rabbie serum. f Clin Endocrinol Metab $1981 ; 53: 200-2$.

15 Czernichow P, Vandalem JL, Hennen G. Transient neonatal hyper $\stackrel{\oplus}{+}$ thyrotropinemia: a factitious syndrome due to the presence of hetero=0 philic antibodies in the plasma of infants and their mothers. $\mathcal{F}$ Clivo Endocrinol Metab 1981;53:387-93.

${ }^{16}$ Biró J. Specific binding of thyroid-stimulating hormone by human serun globulins. F Endocrinol $1981 ; 88: 339-49$.

17 Chaussin JL, Binet E, Job JC. Antibodies to human thyrotrophin in the serum of certain hypopituitary dwarfs. Revue Européenne d'Etudes Cliniques et Biologiques 1972;17:95-9.

${ }^{18}$ Miyai K, Amino N, Nishi K, et al. Transient infantile hyperthyrotropin aemia. Report of a case. Arch Dis Child 1979;54:965-7.

(Accepted 18 November 1982) 